\title{
MCrAlY 合金コーティング部材のクリープ寿命特性*
}

\author{
一高温耐食コーティング部材の寿命特性に関する研究 (第 3 報) 一
}

伊藤 義康**, 斎藤 正弘***, 石渡 裕 ${ }^{* * *}$

\author{
Creep Life Properties of MCrAlY alloy coated Systems
}

-A study for Life Properties of High-Temperature Protective Coated Systems (Report 3) -

\author{
by Yoshiyasu ITOH**, Masahiro SAITOH***, Yutaka ISHIWATA***
}

\begin{abstract}
The low-pressure plasma spray coating process has been established in gas turbine and is used for some parts, such as turbine blades and duct segments, which are exposed to corrosive gases at high temperatures. Overlay coatings based on the MCrAlY alloy system ( $\mathrm{M}$ is Ni and/or Co) are commonly employed as oxidation- and corrosion-resistant coatings. Mechanical properties, such as short-time tensile strength and creep-rupture lives, of CoCrAlY- and CoNiCrAlY-coated systems were investigated at high temperature and compared with the uncoated substrates, such as equiaxis IN738LC, directional solidified CM247LC and single-crystal CMSX-2. As a result, it was clarified that MCrAIY coatings had no significant influence on the tensile strength and creep lives at high temperature. However, the tensile strength at room temperature was reduced for the low-ductility of MCrAlY coatings.
\end{abstract}

Key Words: Low-Pressure Plasma Spraying, MCrAlY Coating, Tensile Strength, Creep-Rupture Life, Gas Turbine, HighTemperature Protective Coatings

\section{1. 緒言}

現在, ガスタービン動翼の高温耐食コーティングには, 減圧プラズマ溶射プロセスが実用化されており，高温での 耐酸化性，耐食性に優れた $\mathrm{MCr} A 1 \mathrm{Y}$ 合金 $(\mathrm{M}$ は $\mathrm{Ni}$ あるい はCO）がコーティング材料として広く適用されている1). しかしながら, MCrAlY 合金皮膜の強度や延性などの機械 的特性は，動翼基材である $\mathrm{Ni}$ 基超合金に比べて必ずしも 優れているとは言い難い2). その結果, コーティング部材の 寿命は酎酸化性, 耐食性以外に, 皮膜に生じる残留応力ゃ 皮膜自体の強度などの機械的特性によっても，大きな影響 を受けることが明らかにされている3 ${ }^{3,4)}$. そこで基材の優れ た高温強度を損なうことのない耐酸化性, 耐食コーティン グ材料の選択と，コーティング施工技術の開発が重要であ る.しかしながら，従来よりコーティング材料選択に関し てはバーナ一加熱などによる比較試験が主として行われて おり,必ずしもコーティング部材の機械的特性に関しては， 十分な定量的研究が行われているとは言い難いのが現状で ある。

\footnotetext{
*原稿受付 平成 9 年 2 月 5 日 平成 8 年 5 月溶接法・溶接構造合 同研究委員会で発表

**正 員 侏東芝 Member, Toshiba Corporation

*** (果芝 Toshiba Corporation
}

著者らは，このような観点から MCrAlY 合金コーティ ングを施した $\mathrm{Ni}$ 基超合金（普通鋳造材料，一方向凝固材 料, 単結晶材料) の高温域での疲労損傷メカニズムを明ら かにし, $\mathrm{Ni}$ 基超合金の疲労寿命に及ぼすコーティングの影 響について実験的検討を加えた. その結果, MCrAlY 合金 コーティングは Ni 基超合金の高温低サイクル疲労寿命を 低下させることはないが，高温高サイクル疲労については MCrAlY 合金コーティングにより寿命が低下することを 明らかにした ${ }^{5,6)}$. しかし，ガスタービン動翼の使用条件を 考えると，クリープ寿命に関しても明らかにする必要があ る. そこで, 本研究では MCrAlY 合金コーティングを施し た $\mathrm{Ni}$ 基超合金(普通鋳造材料，一方向凝固材料，単結晶材 料）を対象とし，高温での引張試験とクリープ試験を実施 した。 また，得られた実験結果はコーティングを施してい ない基材の奉験結果と比較することにより，コーティング 部材の静的負荷による破壊メカニズムを明らかにした。
2. 実
験

\section{1 供試材料}

実験に供した基材は，IN738LC 普通精密鋳造材料と， CM247LC一方向凝固材料, ならびに CMSX-2 単結晶材料 の3 種類であり, Table 1 にその化学組成と熱処理条件を 示す。また, コーティング材料は, 市販の MCrAlY 合金の 
Table 1 Chemical composition of materials used.

\begin{tabular}{|c|c|c|c|c|c|c|c|c|c|c|}
\hline \multirow{2}{*}{ Substrates } & \multicolumn{8}{|c|}{ Chemical composition (mass \%) } \\
\cline { 2 - 11 } & $\mathrm{Ni}$ & $\mathrm{Cr}$ & $\mathrm{W}$ & $\mathrm{Mo}$ & $\mathrm{Co}$ & $\mathrm{A} \ell$ & $\mathrm{Ti}$ & $\mathrm{Nb}$ & $\mathrm{Ta}$ & $\mathrm{Hf}$ \\
\hline IN738LC*1 & $\mathrm{Bal}$ & 15.8 & 2.46 & 1.78 & 8.11 & 3.45 & 3.60 & 0.92 & 1.92 & - \\
\hline CM247LC*2 & $\mathrm{Bal}$ & 8.04 & 9.38 & 0.51 & 9.31 & 5.63 & 0.72 & 0.01 & 3.27 & 1.56 \\
\hline CMSX-2*3 & Bal. & 7.73 & 7.89 & 0.59 & 4.56 & 5.66 & 1.03 & $<0.01$ & 6.07 & $<75 \mathrm{ppm}$ \\
\hline
\end{tabular}

Heat $\quad * 11393 \mathrm{~K} \times 2 \mathrm{~h}$ Ar gas cooled, $1116 \mathrm{~K} \times 24 \mathrm{~h}$ Ar gas cooled

treatment ; $* 21503 \mathrm{~K} \times 2 \mathrm{~h}$ Ar gas cooled, 1353K $\times 4 \mathrm{~h}$ Ar gas cooled, 1143K $\times 20 \mathrm{~h}$ Ar gas cooled

$* 31588 \mathrm{~K} \times 3 \mathrm{~h}$ Ar gas cooled, 1353K $\times 4 \mathrm{~h}$ Ar gas cooled, 1143K $\times 20 \mathrm{~h}$ Ar gas cooled

\begin{tabular}{|c|c|c|c|c|c|c|c|}
\hline \multirow{2}{*}{$\begin{array}{l}\text { Coating } \\
\text { powder }\end{array}$} & \multicolumn{6}{|c|}{ Chemical composition (mass \%) } & \multirow{2}{*}{ Powder size } \\
\hline & Co & $\mathbf{N i}$ & $\mathrm{Cr}$ & $\mathbf{A} \boldsymbol{\ell}$ & $\mathbf{Y}$ & Ta & \\
\hline CoCrAlY & Bal. & $<0.10$ & 28.9 & 6.15 & 0.28 & - & -400 mesh \\
\hline CoNiCrAlY & Bal. & 32.08 & 21.22 & 8.33 & 0.39 & - & -400 mesh \\
\hline CoNiCrAeY+Ta & Bal. & 9.7 & 24.6 & 7.0 & 0.48 & 5.5 & -400 mesh \\
\hline NiCralY & - & Bal. & 31.45 & 11.55 & 0.825 & - & -400 mesh \\
\hline NiCoCrAlY & 23.23 & Bal. & 16.94 & 12.47 & 0.49 & - & -325 mesh \\
\hline
\end{tabular}

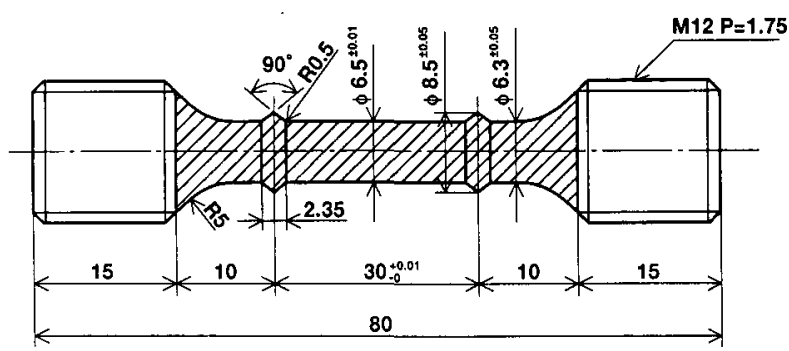

(Creep test specimen)

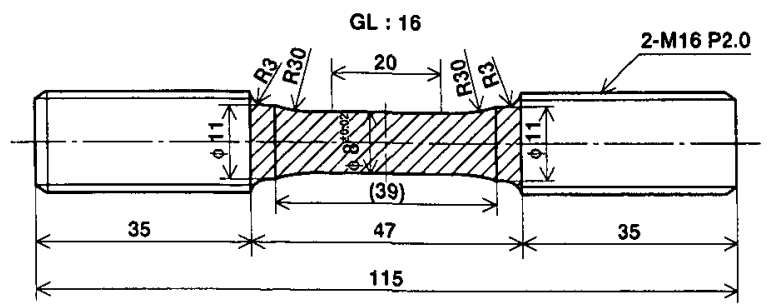

(Tension test specimen)

Unit : $\mathbf{m m}$

Fig. 1 Geometry of specimens.

中から CoCrAlY, CoNiCrAIY, CoNiCrAlY + Ya, NiCrAlY, NiCoCrAlYの 5 種類を選択し，実験に供した。 Table 1 には使用した溶射粉末の化学組成と粒度をまとめ て示す.
Fig. 1 にはクリープ試験体と引張試験体を示す．丸棒を 精密鋳造で作製した後に，減圧プラズマ溶射装置 (Plasma Tecknik A-2000V VPS System) を用い, CoCrAlY, CoNiCrAlY, NiCrAlY 合金粉末を予熱温度 $843 \mathrm{~K}$, 電圧 64 $\mathrm{V}$, 電流 $685 \mathrm{~A}$, アルゴンガス雾囲気圧 $6 \mathrm{kPa}$, 溶射距離 270 $\mathrm{mm}$ の条件でコーティングした後に，アルゴンガス雾团気 中でTable 1 中に示す拡散熱処理を施した。ただし， CM247LC と CMSX-2 は Table 1 中に示寸 2 段目と 3 段 目の熱処理を施した。皮膜表面は実機ガスタービン動翼に 合わせて，ピーニング処理により表面粗さ $\mathrm{Ra}=1.0 \mu \mathrm{m}$ に 仕上げて実験に供した. MCrAlY 合金コーティング部位は Fig. 1 に示す斜線部分であり, 平行部の最終仕上げ皮膜厚

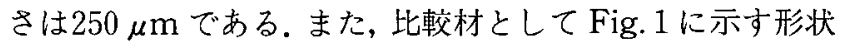
のコーティングを施さない基材のみの試験体を作製した。 試験体の表面粗さは軸方向に\#600エメリペーパを用いて $\mathrm{Ra}=0.2 \mu \mathrm{m}$ に仕上げて実験に供した.

\section{2 実験方法}

引張試験はストローク制御, 負荷速度 $1 \mathrm{~mm} / \mathrm{min}$. で, 大 気中において室温 $(293 \mathrm{~K})$ と電気炉加熱による $1123 \mathrm{~K}$ の条 件でJIS G 0567 に従って実施した. $293 \mathrm{~K}$ ではひずみゲー ジ, $1123 \mathrm{~K}$ では試験体平行部の標点距離16 $\mathrm{mm}$ での軸方 向変位を押し当て式変位計により測定した。クリープ破断 試験は縦型単テコ荷重式自立型クリープ試験装置を用い, 
大気中で電気炉加熱により $1123 \mathrm{~K}$ と $1173 \mathrm{~K}$ の条件で JIS Z 2271 に従って実施した.クリープ伸びの測定は差動卜ラ ンスにより行った。試験体に作用する応力の算出にはコー ティング皮膜の厚さを考慮せず，荷重を基材のみの断面積 で除することにより求めた。

また, MCrAlY 合金皮膜の四点曲げ強度の測定は, 皮膜 のみからなる $50 \times 5 \times 1.5 \mathrm{~mm}$ の試験片を切り出し加工で 製作し，オートグラフ (島津製作所製 AG-10T)により変 位速度 $1 \mathrm{~mm} / \mathrm{min}$. で測定を行った. 同様に, $5 \times 10 \times 5 \mathrm{~mm}$ の試験片を切り出し加工により製作し, 高温硬さ計(Nikon -QM）により測定荷重 $2.9 \mathrm{~N}$, 負荷時間 $15 \mathrm{~s}$ で測定を行っ た.

\section{3. コーティング部材の高温引張特性}

耐食, 耐酸化コーティング皮膜が基材の機械的特性を著 しく損なうことは，ガスタービン翼の強度設計において大 きな問題となる。すなわち，ガスタービン翼設計において 強度は基材，耐環境性はコーティング皮膜が受け持つ機能 分担が一般的な考え方である。このような観点から，Fig. 2 には普通鋳造材料 IN738LC と比較して CoCrAlY, CoNiCrAlY 合金コーティングを施した IN738LC 試験体につい て, 室温 $(293 \mathrm{~K})$ と $1123 \mathrm{~K}$ における引張試験を行った結果 を比較して示す。図から明らかなように, 室温 $(293 \mathrm{~K})$ と $1123 \mathrm{~K}$ いずれにおいても，IN738LC 基材の $0.2 \%$ 耐力 $\sigma_{0.2}$ と引張強さ $\sigma_{\mathrm{u}}$ は, コーティングを施すことで顕著な強度
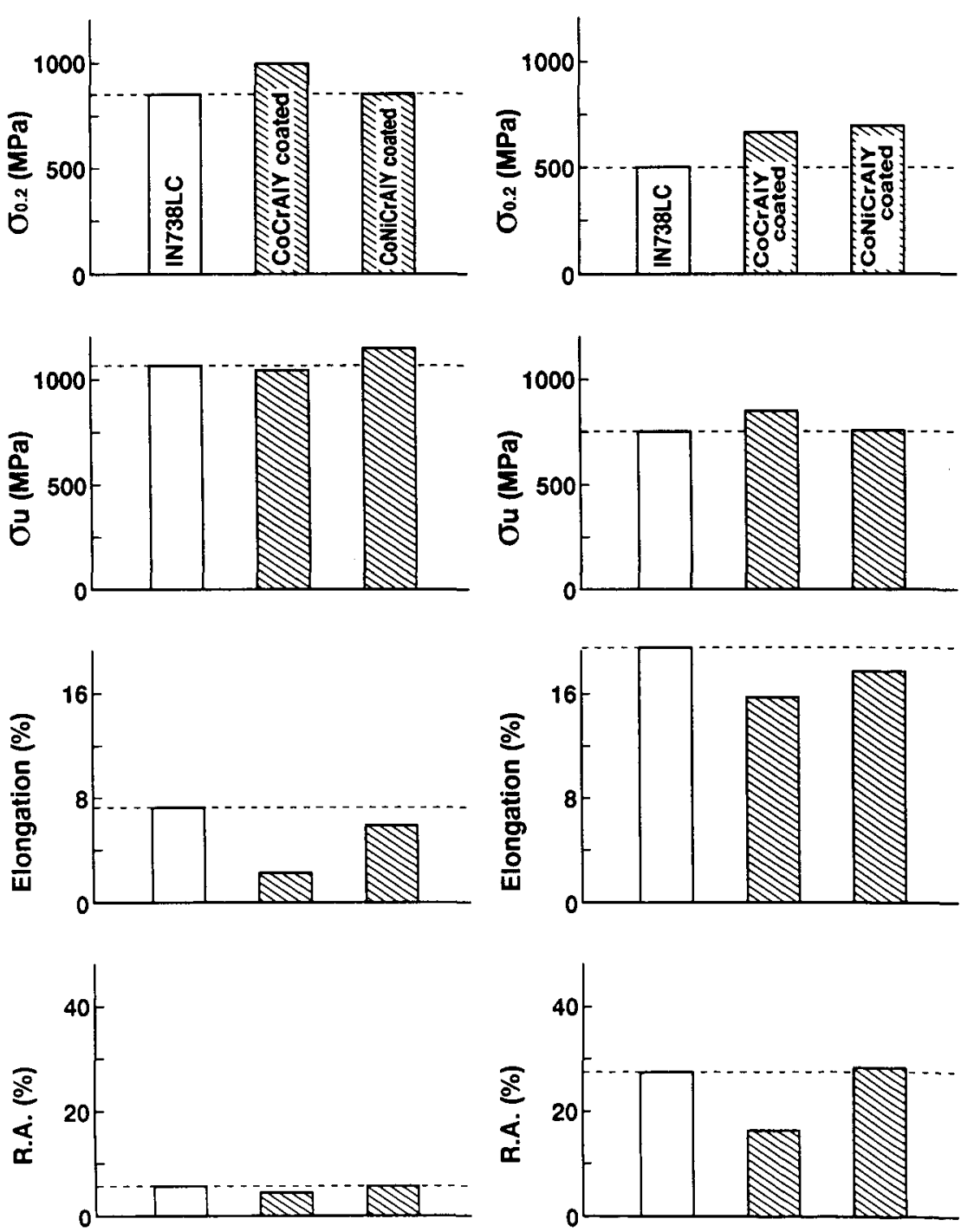

Test temp.: 293K

Test temp.: 1123K

Fig. 2 Comparison of tensile test results between $293 \mathrm{~K}$ and $1123 \mathrm{~K}$. 
低下は生じないことが分かる。むしろ, 試験温度 $1123 \mathrm{~K}$ で はコーティング部材の強度は基材単独よりも向上する傾向 が認められるようである.しかし，破断時の伸び，絞り R. A.についてはコーティングを施すことでIN738LC 基材よ りも低下する傾向が認められる。特に, この傾向は室温の 試験結果において明瞭であり, さらに CoNiCrAlYよりも CoCrAlY コ一ティング試験体の伸び，絞りの低下は顕著 である。

Fig. 3 (a)には CoCrAlY コーティング試験体の室温（293 K) と $1123 \mathrm{~K}$ での引張破断状況，(b)には CoNiCrAlY コー ティング試験体の引張破断状況を示す。図から明らかなよ うに, CoCrAlY コーティング試験体の場合には, 室温の引 張試験では破断部以外にも引張軸方向と垂直に多数のき裂 が生じていることが分かる.この観察された多数のき裂は, いずれも CoCrAlY コーティング層と, 基材との間に形成 された拡散層内で止まっており, 破断部以外は基材に到達 していないことが断面観察により確認された。一方, CoNi$\mathrm{CrAlY}$ コーティング試験体の場合には, 室温の引張試験に おいて皮膜に生じたき裂が最終破断位置となることが観察 された。また, $1123 \mathrm{~K}$ ではコーティング試験体についても 十分な延性を示した後に破断した。このような観察結果か ら, MCrAlY コーティング試験体の室温における強度の向 上と破断伸び, 絞りの低下は, 引張試験の過程で低延性の

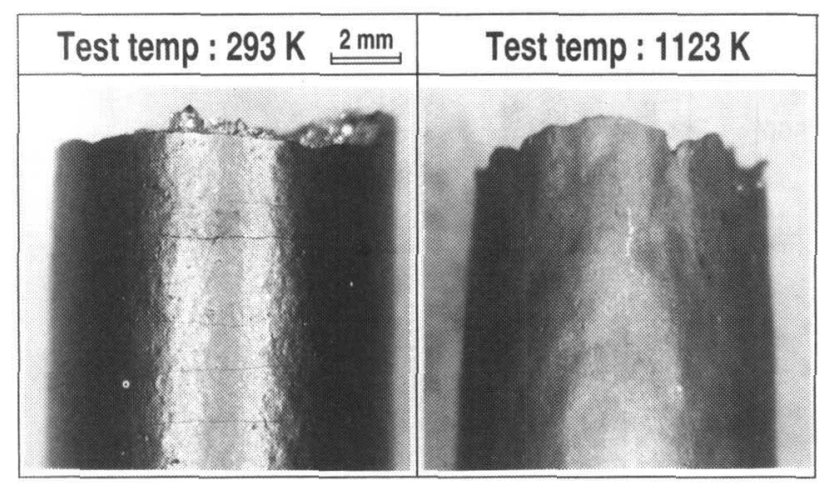

(a)

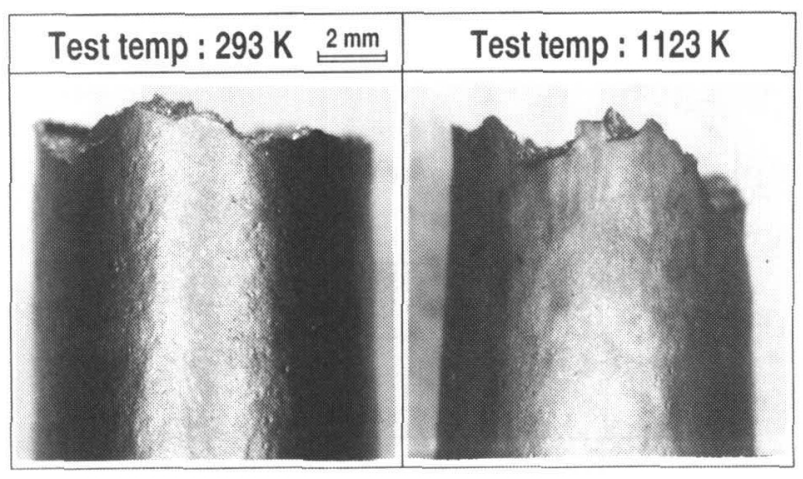

(b)

Fig. 3 Fractured appearance of tensile test specimens. (a) CoCrAlY coated IN738LC.

(b) $\mathrm{CoNiCrAlY}$ coated IN738LC.
MCrAlY コーティング皮膜 ${ }^{3,4)}$ にき裂が生じ，この切欠き 効果によるものと考えられる.

\section{4. コーティング部材のクリープ破断寿命}

実験の結果, $\mathrm{Ni}$ 基超合金基材と $\mathrm{MCrAlY}$ コーティング 部材とで, クリープ曲線の形態には大きな差は認められな かった. そこで, IN738LC 普通精密鋳造材料と, CM247LC 一方向凝固材料, ならびに CMSX-2単結晶材料と, その MCrAlY コーティング部材のクリープ破断寿命を Fig. 4 にまとめて示す. IN738LC 基材と, その MCrAlY コーティ ング部材の試験結果は試験温度 $1123 \mathrm{~K}, 1173 \mathrm{~K}$ におけるデ 一夕をまとめたものである。また, CM247LC, CMSX-2基 材と, その CoCrAlY コーティング部材の試験結果は, 試験 温度 $1173 \mathrm{~K}$ におけるデー夕をまとめたものである.また， 図中に示す実線は従来より得られている各基材の実験デ一 夕を連ねたものである ${ }^{3,7)}$. 当然のことであるが試験温度が 高いほど, 負荷応力が高いほどクリープ破断寿命は低下す る傾向を示すが, クリープ破断寿命はIN738LC< CM247LC<CMSX-2の順に高くなることが分かる．また， これらの基材データと MCrAlY コーティング部材のデー 夕の間に顕著な差は認められない.すなわち, MCrAlY コ 一ティング皮膜の荷重分担は，本実験の範囲内では無視出 来る程度と考えられる.クリープ破断寿命に関しても IN738LC, CM247LC, CMSX-2 基材と, れぞれの $\mathrm{MCrAlY}$ コーティング部材のデータの間に顕著な差は認 められない.さらに, IN738LC の MCrAlY コーティング部 材において, CoCrAlY, CoNiCrAlY, NiCrAlY コーティ ング部材のデータ間にも明瞭な差は認められない.

一方, 従来から各種材料に関して, 最小クリープ速度 $\dot{\varepsilon}_{\min }$ と破断寿命 $\mathrm{t}_{\mathrm{s}}$ の間には次式の関係が成立することが知ら

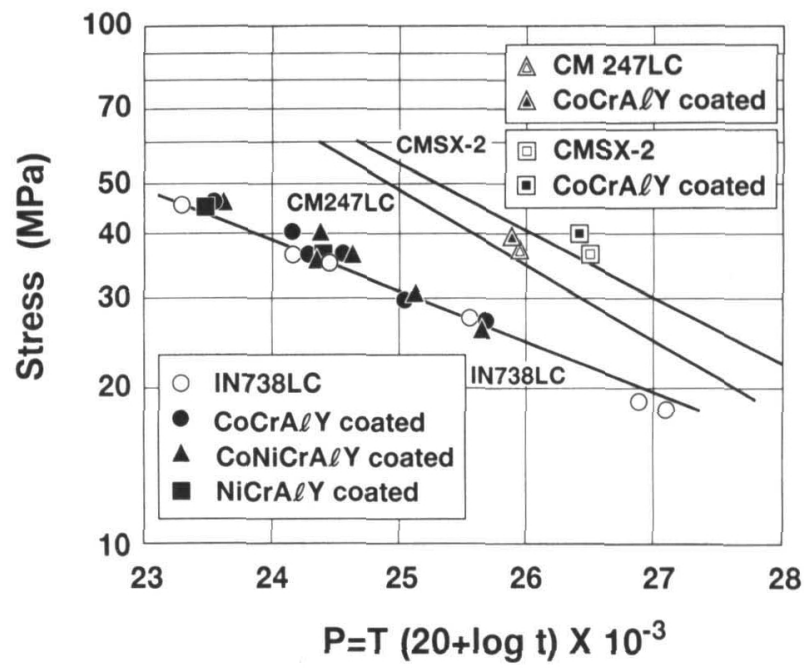

Fig. 4 Effect of MCrAlY coatings on master rupture curves. 


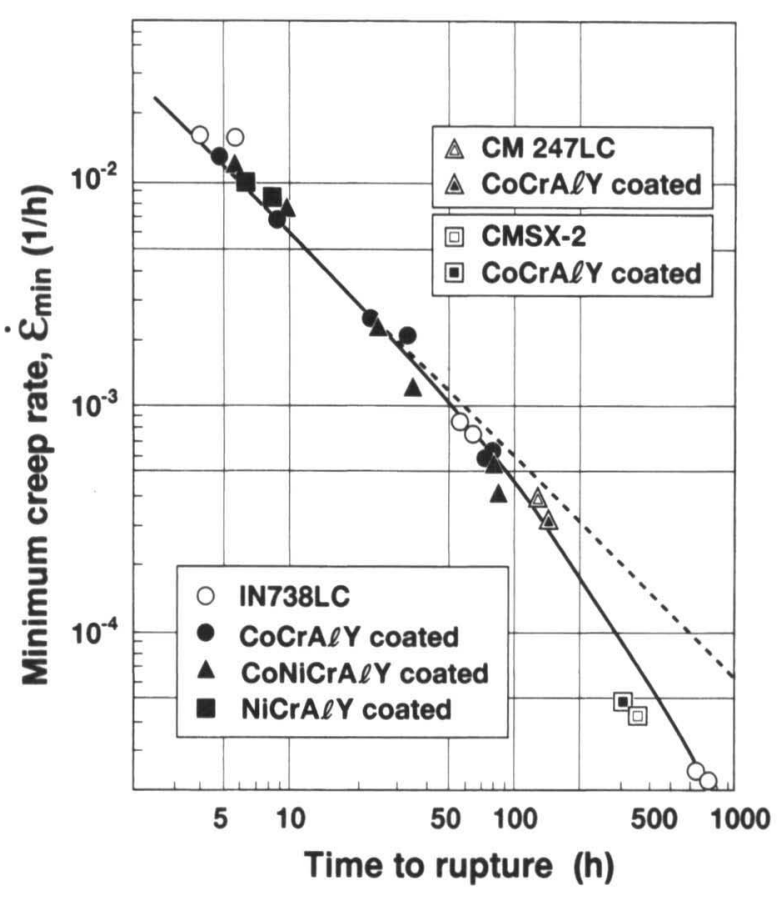

Fig. 5 Effect of MCrAlY coatings on minimum creep rate curve.

れている8).

$\dot{\varepsilon}_{\text {min }} \cdot t_{\mathrm{s}}=$ const.

Fig. 5 には，本研究において得られたクリープデー夕を プロットした結果を示す、ほぼ，眓中に示す右下がり $45^{\circ}$ の 傾きの直線にデータが乗ることから，短寿命側では式(1)が 本研究においても成立することが分かる。ささらに，CoCrAlY, CoNiCrAlY, NiCrAlY コーティング試験体のク リープデータも IN738LC，CM247LC，CMSX-2基材とほ ぼ同一線上で表されることも明らかである。また，低クリ

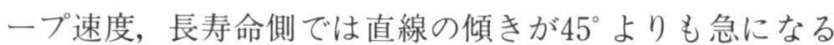
傾向が耐熱鋼で得られているが，本研究においても同様な 傾向が認められる.

クリープき裂の進展状況を明らかにするため, 試験条件 $1123 \mathrm{~K} ， 353 \mathrm{MPa}$ で実施したIN738LC 基材とCoNiCrAlY コーティング試験体の縦断面を光学顕微鏡により 観察した結果を Fig. 6 に示す。四から明らかなように，ク リープき裂は IN738LC 基材のデンドライト粒界に沿って 発生，進展していることが分かる。しかし，基材にクリー プき裂が発生し，進展しているにもかかわらず，コーティ ング皮膜中には明瞭なき裂は観察されなかった。従って， MCrAlY コーティング部材のクリープ破断寿命は IN738LC 基材のクリープ破断寿命で決定され， MCrAlY コーティング皮膜は荷重分担を行わないと共に，クリープ き裂の発生要因にもならないことが分かる.Fig. 7 には $1173 \mathrm{~K}$ で実施したCM247LC 基材と CoCrAlY コーティ ング試験体のクリープ破断後の縦断面を光学顕微鏡により 観察した結果を示す。クリープき裂は CM247LC 基材の結
晶粒界において発生し, 結晶粒内に進展することが確認さ れた。この破断様相は CoCrAlY コーティング試験体にお

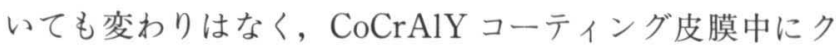

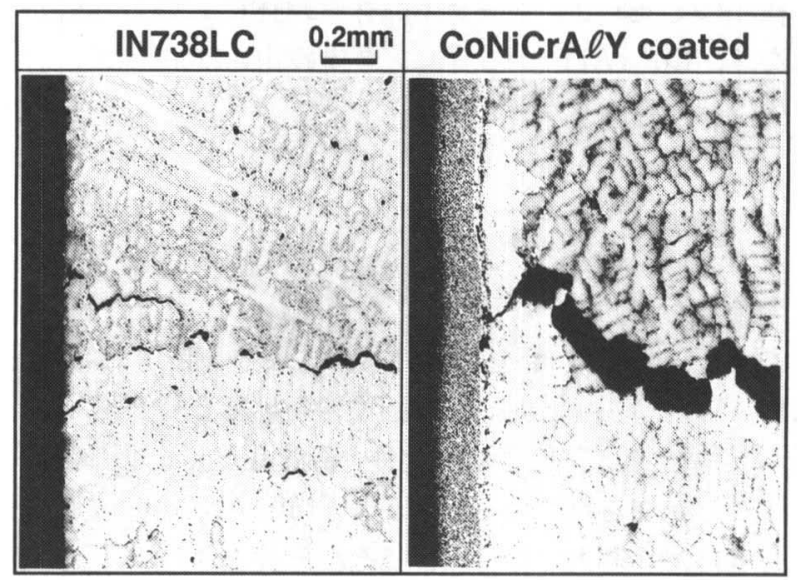

Fig. 6 Macrophotographs of creep crack growth in case of IN378LC.

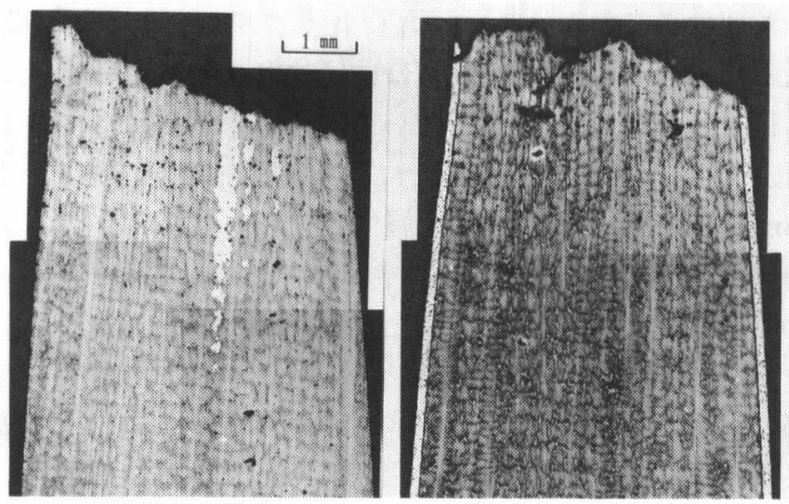

(a) CM247L C

(b) Coated CM247 L C

Fig. 7 Cross-section of creep ruptured specimen in case of CM247LC.

(a) CM247LC.

(b) Coated CM247LC

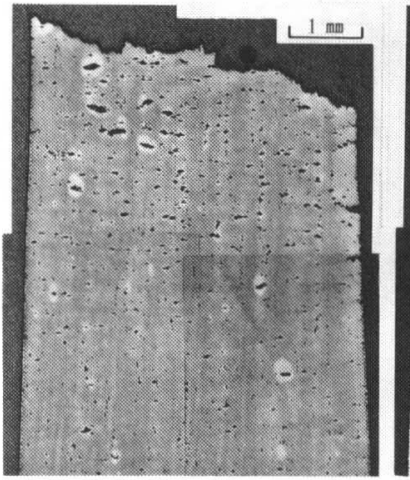

(a) CMSX-2

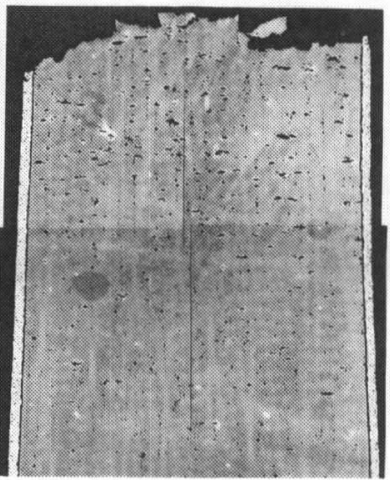

(b) Coated CM S X-2
Fig. 8 Cross-section of creep ruptured specimen in case of CMSX-2.

(a) CMSX-2.

(b) Coated CMSX-2. 
リープき裂の発生は認められなかった。同様に, Fig. 8 には $1173 \mathrm{~K}$ で実施したCMSX-2基材と CoCrAlY コーティン グ試験体のクリープ破断後の縦断面を光学顕微鏡により観 察した結果を示す．単結晶基材においても，クリープき裂 は多発し，連結しながら進展する様子が明らかである。こ の様相は CoCrAlY コーティング試験体においても変わり はなく, CoCrAlY コーティング皮膜中にクリープき裂の 発生は認められなかった。

\section{MCrAlY コーティング部材の破壊メカニズム}

各種 MCrAlY コーティング皮膜自体の, 室温 (293 K) での四点曲げ強度を测定した結果をFig. 9 に示す。 MCrAlY 合金中に含まれる酸化皮膜生成元素である Al, Cr 量が增すと, 一般に耐酸化性, 耐食性が良くなる傾向を 示すことが知られている。しかし，MCrAlY 合金皮膜自体 の強度は, $\mathrm{Ni}$ 基あるいは $\mathrm{Co}$ 基それぞれで $\mathrm{Al}, \mathrm{Cr}$ 量が増す と逆に低下する傾向を示すことが分かる。すなわち，比較 的 $\mathrm{Al}, \mathrm{Cr}$ 量少ない $\mathrm{CoNiCrAlY}$ 合金皮膜は高い曲げ強度

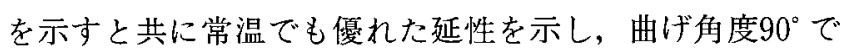
もき裂は生じなかった。これに比べて $\mathrm{Al}, \mathrm{Cr}$ 量多いCo$\mathrm{CrAlY}, \mathrm{NiCr} A 1 \mathrm{Y}$ 合金皮膜は曲げ強度が低く, 荷重一たわ み関係が線形の状態でぜい性的に破断した。これは MCrAlY 合金は, Table 1 に示す拡散熱処理を施すと数 $\mu \mathrm{m}$ 程度のぜい性な $\mathrm{Al}$ 系金属化合物が析出し, $\mathrm{Al}, \mathrm{Cr}$ 量が 60 vol\%を越える場合には，ネットワーク形状を示すため と考えられる2. Fig. 2で示した室温引張試験において,

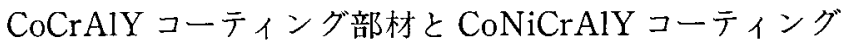
部材に認められた伸び，絞りの差は，このコーティング皮 膜の延性の差によるものと考えられる。すなわち， MCrAlY コーティングを施した部材では，低延性のCo-

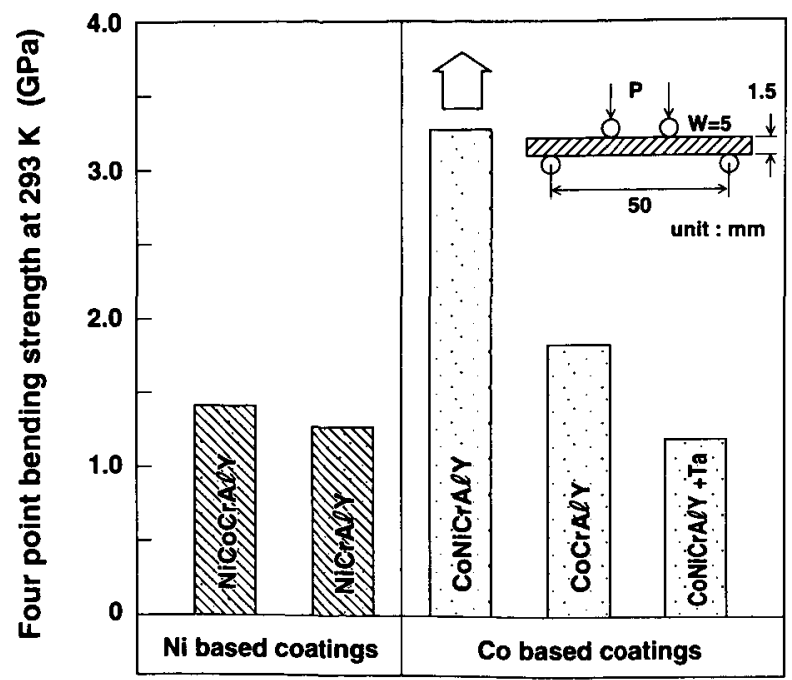

Fig. 9 Four-point bending strength of various $\mathrm{MCrAlY}$ alloys at $293 \mathrm{~K}$.
CrAlY 皮膜には低負荷段階でき裂が生じ，高延性の CoNiCrAlY 皮膜にはき裂が生じない. 低延性の CoCrAlY 皮膜 に生じたき裂は，直ぐに基材に進展しないが，Uずみ集中

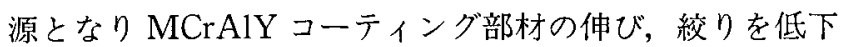
させると考えられる。

また, MCrAlY コーティング部材には, 基材と MCrAlY 合金皮膜との熱膨張係数差による残留応力が室温で生じ る.この残留応力は, ぜい性な MCrAlY 皮膜強度には大き な影響を及ぼすものと考えられる。このような観点から， 板厚 $5 \mathrm{~mm} の \mathrm{IN} 738 \mathrm{LC}$ 基材片面に膜厚 $0.3 \mathrm{~mm} の$ $\mathrm{MCr} A 1 \mathrm{Y}$ 合金皮膜を形成した場合の残留応力を, X線応力 測定法により测定した. 得られた結果からは, Fig. 10 に示 すように CoCrAlY や CoNiCrAlY コーティング皮膜には 60 70 MPa の引張残留応力が, NiCrAlY コーティング皮 膜には70 MPa の圧縮残留応力が確認された。室温での引

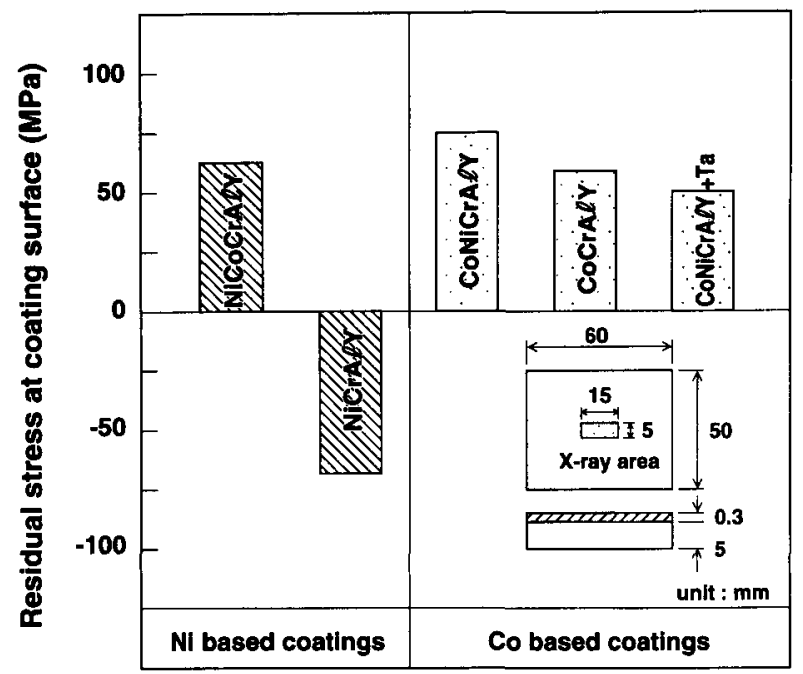

Fig. 10 Residual stress of various MCrAlY coatings in case of IN738LC substrate.

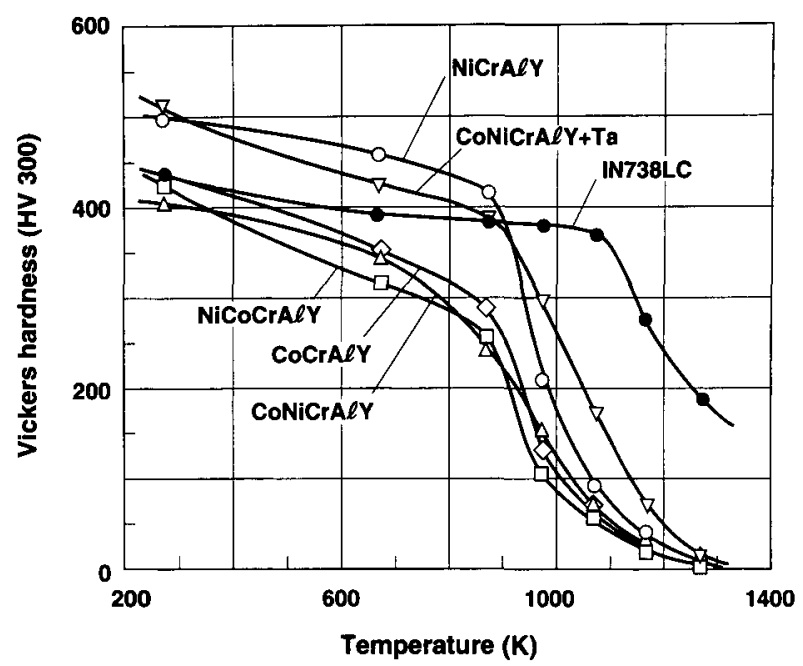

Fig. 11 Temperature dependency of Vicker's hardness for various $\mathrm{MCrAlY}$ coatings. 
張試験過程での低延性材料である CoCrAlY 合金皮膜にお けるき裂発生は，この引張残留応力が助長していると考之 られる。また，高温での引張強度，クリープ破断寿命に関 しては，残留応力の影響は無いようである.

一方，Fig. 11 には各種 MCrAlY 合金皮膜の硬さの温度 依存性を示す. MCrAlY 合金皮膜は一般に室温付近では高 強度，低延性であり，図から硬さが高いことが分かる。し かし, $900 \mathrm{~K}$ 程度を境にして硬さが急激に低下し, 顕著な軟 化傾向，すなわ力低強度，高延性化を示す。困から，本研 究で実験に供した MCrAlY 合金皮膜のぜい性一延性遷移 温度は900 $1000 \mathrm{~K}$ と考えられる ${ }^{3,4)}$.したがって, 本研究で 実施した高温引張試験，ならびにクリープ試験は $1100 \mathrm{~K}$ 以 上の温度域であり，IN738LC 基材と比べて十分に硬さが低 下しており，MCrAlY 合金皮膜は低強度，高延性を示すこ とが分かる.したがって, 本研究で実施した高温引張試験, ならびにクリープ試験の温度域では, MCrAlY 合金皮膜は 基材に比べて低強度のため，ほとんど荷重負担を行わず， 基材なみの延性となるためにき裂発生要因ともならないと 考えられる。

以上より，MCrAlY 合金皮膜のぜい性-延性遷移温度以 上では，耐酸化性，耐食性は MCrAlY 合金皮膜が受け持 ち，高温強度やクリープ破断寿命などの静的負荷による機 械的特性は基材が受け持つ機能分離が成立していることが 分かる。しかし，ぜい性一延性遷移温度以下では，基材にき 裂が生じる前に $\mathrm{MCrAlY}$ 合金皮膜にき裂が生じること で，基材の機械的特性を著しく損なうことが考えられこ れを考慮する必要があると考えられる。

\section{6. 結論}

(1) 室温 $(293 \mathrm{~K})$ と $1123 \mathrm{~K}$ の引張試験により IN738LC 基材の $0.2 \%$ 耐力と引張強さは, CoCrAlY コーティングによる顕著な強度低下は認められない。しか し, 室温での CoCrAlY コーティング部材では, 引張試験過 程で皮膜にき裂が生じることで破断時の伸び，絞りは基材 よりも低下寸る傾向が認められた。
(2) 試験温度 $1123 \mathrm{~K}, 1173 \mathrm{~K}$ のクリープ変形挙動とクリ 一ブ破断寿命に関して, IN738LC, CM247LC, CMSX-2 基 材と, れらの MCrAlY コーティング試験体との間に大 きな差は認められないことから，MCrAlY 合金皮膜はほと んど荷重負担を行わないと共にクリープ損傷にも影響を及 ぼさない.

(3) IN738LC, CM247LC, CMSX-2 基材の MCrAlY コ 一ティング部材においても，クリープき裂は基材において 発生, 進展しており，クリープ破断寿命は基材の寿命で決 定されている。すなわち, MCrAlY コーティング皮膜はク リープき裂の発生要因にならない。

(4) MCrAlY 合金皮膜のぜい性一延性遷移温度以上で は, 耐食性は皮膜が受け持ち, 高温強度やクリープ破断寿 命などの静的負荷による機械的特性は基材が受け持つ機能 分離が成立している。しかし，ぜい性一延性遷移温度以下で は MCrAlY 合金皮膜にき裂が生じ，基材の機械的特性を 著しく損なう。

\section{参 考 文 献}

1）伊藤，斉藤，宮崎，本多，杉山，“ガスター-ビン翼の高温耐食コ ーティング(1)，(2)”機械の研究，44-2(1992)，257，44-3(1992)， 369.

2）伊藤, 斉藤, 宮崎, 本多, “減圧プラズマ溶射 MCrAlY 合金皮膜 の機械的特性” 材料, 43-489 (1994)，690.

3) K. Schneider, H.W. Grunling, "Mechanical aspects of high temperature coatings", Thin Solid Films, 107 (1983) 395.

4) M.I. Wood, "The mechanical properties of coatings and coated systems", Materials Science and Engineerig, A121 (1989) 633.

5）伊藤，齐藤，石渡, “MCrA1Y 合金コーティング部材の低サイク 儿疲労寿命特性”溶接学会論文集, 15-1（1997）141.

6）伊藤, 斉藤, 石渡, “MCrAlY 合金コーティング部材の高サイク 儿疲労寿命特性”溶接学会論文集, 15-2（1997） 359 .

7) H. Yamamoto, M. Yamamoto, K. Imai, M. Miyazaki, M. Satoh, Y. Kobayashi, H. Matsuzaki, "Material evaluation of large single crystal and directionally solidified bucket castings for advanced land-based gas turbines", ASME paper, 95 -GT-449 (1995). 